\title{
OSOBNE GRANICE KAO TEMELJ INTERPERSONALNIH ODNOSA I SKRBI ZA SAMOGA SEBE
}

\author{
Irena Sever Globan
}

Hrvatsko katoličko sveučilište

UDK: (366.632+159.922.2)

Odjel za komunikologiju

irena.sever@unicath.hr

https://doi.org/10.34075/cs.56.3.5

Pregledni znanstveni rad

Rad zaprimljen 5/2021.

\section{Sažetak}

Članak se bavi temom definiranja $i$ promišljanja o osobnim $i$ relacijskim granicama u kontekstu skrbi za vlastito psiho-fizičko $i$ duhovno zdravlje. Osobne granice pomažu nam da definiramo naš osobni identitet, integritet, bliske odnose i pridonose stvaranju osjećaja sigurnosti. One se uče već od najranijeg djetinjstva, a kakve će granice biti, uvelike ovisi o tome kako su roditelji/skrbnici komunicirali vlastite granice te jesu li poštivali djetetov osobni integritet i moguća neslaganja. Prepoznavanje, postavljanje i komuniciranje osobnih granica imaju i svoje biblijske temelje budući da Bog i u Starom i u Novom zavjetu zna reći „ne" te i čovjeku daruje slobodnu volju dopuštajući mu slobodu izbora. Ovaj članak želi definirati što su to osobne granice, kako se razvijaju, koja je razlika između „zdravih“ $i$ „,bolesnih" granica, kako nam postavljanje osobnih granica može pomoći u izgradnji boljih interpersonalnih odnosa te kako se ideja o granicama uklapa u kršćansku antropologiju. U tom kontekstu će se progovoriti i o asertivnosti kao komunikacijskoj vještini kojom komuniciramo osobne granice na ispravan i zdrav - neagresivan, neosuđujući i nereaktivan - način.

Ključne riječi: granice, asertivnost, interpersonalni odnosi, integritet, odgovornost, kršćanstvo i granice

\section{UvoD}

Briga i skrb o sebi podrazumijevaju zdravu ljubav prema samome sebi, a ona se očituje kroz upoznavanje i prihvaćanje sebe, vlastitih želja i potreba te mogućnosti da te želje i potrebe sebi priznamo te ih ispravno komuniciramo drugima. Upravo se $\mathrm{u}$ tom procesu oblikuje ono što nazivamo osobnim granicama koje možemo definirati kao unutarnji prostor $\mathrm{u}$ kojem završava moje fizičko i psihičko 
ja, a počinje nečije tuđe. ${ }^{1}$ Granicama zapravo otkrivam i definiram tko sam ja u odnosu na sebe, na drugog i za razliku od drugog. Sam pojam i fenomenologija unutarpsihičkih granica nije nešto što bi bilo otkriće suvremenog doba budući da je riječ o nečemu što ulazi u samu narav čovjekove osobnosti, međutim o njima se u javnom diskursu više počelo govoriti upravo unatrag nekoliko desetljeća, i to usporedno s rastom svijesti o važnosti ljudskih prava, dostojanstva svake ljudske osobe te s razvojem individualne, socijalne, razvojne i popularne psihologije. Često se tako čuje u međuljudskim razgovorima kako jedni drugima dijelimo savjete oko važnosti postavljanja granica drugima, posebno kada je riječ o poslovnoj i obiteljskog sferi. Međutim, to uvijek više zvuči kao da nekog drugog trebamo staviti „u red“ i pokazati mu gdje mu je mjesto i gdje su njegove granice, a ne kao oblik brige za sebe i za vlastite granice. No što točno podrazumijevamo pod granicama, kako se i kada one postavljaju, te kako se ispravno komuniciraju drugima nije uvijek u potpunosti jasno, posebno zato što i u znanstvenoj literaturi ne nailazimo na unificirane i jasne definicije.

Uz to, postoje i mnoge predrasude kada je o granicama riječ, posebno u kontekstu kršćanskog poimanja čovjeka i ideala ljubavi prema bližnjima. Naime, postoji konstantna napetost između Isusove zapovijedi ljubavi prema sebi i ljubavi prema bližnjemu, što vjernicima često na praktičnoj razini življenja postaje teška za obnašanje. Kako usuglasiti te dvije ljubavi? Kršćani mogu imati problem s definiranjem granica ili, točnije, komuniciranjem svojih granica kroz odbijanja tuđih molbi i zahtjeva budući da se nečije „ne“ često izjednačuje s egocentrizmom, pretjeranim sebeljubljem i individualizmom. Isusova želja da ljubimo bližnje kao sebe same (Mt 22,3440) u misli se mnogih kršćana pretvorila u „ljubi bližnjega svoga usprkos ili nauštrb sebe samoga“. Ljubav i briga o sebi, skrb za vlastito duhovno i emocionalno vlasništvo - o čemu govori i apostol Pavao kada kaže da smo hram Duha Svetoga i da moramo proslaviti Boga kroz svoje tijelo (1 Kor 6,9-12) - u kršćanskoj se antropologiji, možda ne na teoretskoj, ali da na praktičnoj razini, tako nerijetko izjednačuje sa sebičnošću. U isto vrijeme, neprepoznavanje i kršenje vlastitih granica dovodi do manjka samopouzdanja i grizodušja, ali i mnogih drugih psihosomatskih tegoba. Da je tema granica među kršćanima aktualna i plijeni veliku pažnju, pokazuje i činjenica da je knjiga koja je posvećena granicama u kontekstu kršćanskog praktičnog života, Granice. Kada reći 'da', kako reći 'ne' i preuzeti nad-

$1 \quad$ Usp. Charles L. Whitfield, Boundaries and relationships: knowing, protecting and enjoying the self, Health Communications, Florida, 2010., str. 1. 
zor nad svojim životom Henryja Clouda i Johna Townsenda postala svjetski hit i da već više godina ne silazi s top-ljestvica čitanosti te je prodana u preko 4 milijuna primjeraka. ${ }^{2}$

Upravo iz tog razloga smatramo važnim progovoriti o pitanju i definiranju unutarpsihičkih i psihodruštvenih granica: definirati što su one, koje vrste granica postoje, kada su one zdrave, a kada su bolesne, vidjeti u kojem odnosu stoje s obzirom na ljubav prema sebi i bližnjima, a na koncu promisliti i o tome kako se pojam granica uklapa u kršćansku antropologiju te kako se one adekvatno komuniciraju. Mogu li reći „ne“, nekoga indirektno povrijediti te i dalje biti dobra kršćanka? Mogu li nekome uskratiti svoje vrijeme, svoj novac, svoje talente te i dalje biti altruistična i empatična osoba? Ta nam se pitanja i promišljanja vezana uz unutarnje granice čine još važnijima uzmemo li u obzir da se ove teme još nisu obrađivale u okviru znanstvenih članaka unutar hrvatske akademske zajednice, dok i na svjetskoj razini ne nailazimo na mnogo znanstvenih tekstova i istraživanja s obzirom na pitanje granica u interpersonalnim odnosima. Kada se i pojave, najčešće se o njima raspravlja u kontekstu odnosa medicinskih djelatnika i pacijenata ili pak u kontekstu kršenja granica kod žrtava seksualnog zlostavljanja, a što će biti vidljivo i po naslovima izvora koji su korišteni u ovome članku.

Teza od koje se polazi u ovom promišljanju o granicama i njihovoj asertivnoj komunikaciji, jest da su granice važne za osobni rast i razvoj te da je briga o njima odraz skrbi o vlastitom psiho-fizičkom i duhovnom zdravlju. Granice nam pomažu da definiramo i čuvamo vlastitu dušu i brinemo se za nju, odraz su Božjeg nauma o čovjeku kao i Božje skrbi za čovjeka. Kada ih asertivno štitimo i komuniciramo, zapravo pokazujemo da brinemo o sebi te da smo odgovorni za sebe i odgovorni prema životu.

\section{DEFINICIJA: ŠTO SU TO GRANICE?}

U znanstvenoj literaturi ne nailazimo na jednoznačnu ili eksplicitnu definiciju granica u psihološkom smislu te riječi. Granice su apstraktni pojam, a temeljna im je odrednica da se odnose na ljudsko biće koje je u relaciji s drugim. Horner na primjer uspoređuje unutarnje granice osobe $s$ njezinim osobnim prostorom te kaže da su „(o)sobni prostor i unutarnja granica sociološki i intrapsihološ-

2 Usp. https://www.boundariesbooks.com/pages/about-the-boundaries-bookseries (1.5.2021.) 
ki koncepti koji se odnose na kompleks bihevioralnih i subjektivnih događaja između i unutar pojedinaca“. ${ }^{3}$ Autori razlikuju temeljno dvije vrste granica: osobne i relacijske, a koriste različite definicije kao i vizualne metafore kojima ih opisuju, poput nevidljive propusne membrane, zida koji dijeli dva entiteta ili ograde koja predstavlja među nečijeg posjeda. Bez obzira o kojoj se vrsti granica radilo, zajedničko im je da igraju važnu ulogu u „održavanju homeostaze tijekom psiholoških transakcija pojedinca sa svijetom“. ${ }^{4}$

\subsection{Osobne granice}

Townsend i Cloud osobne granice definiraju kao unutarnji prostor u kojem završavam ja, a počinje netko drugi. ${ }^{5}$ Evans opisuje osobne granice kao psihički balon koji okružuje svaku osobu i pomaže odvojiti ljude jedne od drugih. ${ }^{6}$ McEvoy pak govori o nevidljivoj crti razgraničenja koja okružuje fizički, emocionalni i psihički prostor osobe te kontrolira protok informacija, osjećaja i fizičkog kontakta između dvoje ili više ljudi. ${ }^{7}$ Osobne granice definiraju tko smo u odnosu na vlastitu okolinu, koje su naše želje, mogućnosti, potrebe, odgovornosti. Kod osobnih je granica riječ o strukturi unutar sustava mentalne reprezentacije tijela, društvenih uloga i ostalih kategorija sebstva. Kao što tvrde Strauss i Clark, razvijene i jasno definirane osobne granice neophodne su za normalan razvoj identiteta $u$ adolescenciji ${ }^{8}$, omogućuju regulaciju ravnoteže između privatnosti i intimnosti te variraju u propusnosti i fleksibilnosti s obzirom na ulazne i izlazne podražaje. ${ }^{9}$

3 Thomas Horner, On the formation of personal space and self-boundary structures in early human development: The case of infant stranger reactivity, Developmental Review, 3 (1983.), str. 148.

4 Seymour Fisher, Sidney Cleveland, Body image and personality, Dover, New York, 1968., str. 354.

5 Usp. Henry Cloud, John Townsend, Granice. Kada reći "da", kako reći "ne" i preuzeti nadzor nad svojim životom, Verbum, Split, 2019., str. 24.

$6 \quad$ Usp. Sue Evans, Shame, boundaries and dissociation in chemically dependent, abusive and incestuous families, Alcoholism Treatment Quarterly, 4 (1988.), 2, str. 157-179.

7 Usp. Maureen McEvoy, Repairing personal boundaries: Group therapy with survivors of sexual abuse, u: Toni Laidlaw, Cheryl Malmo (ur.), Healing Voices: Feminist Approaches to Therapy with Women, Jossey-Bass, San Francisco, 1990., str. 62-79.

8 Usp. Sarah Strauss, Bernardine Clarke, Decision-making patterns in adolescent mothers, Journal of Nursing Scholarship, 24 (1992.), 1, str. 69-74.

9 Usp. Anne Scott, Psychometric evaluation of the Personal Space Boundary Questionnaire, Journal of Theory Construction and Testing, (1997.), 2, str. 46-53. 
U osobne bi granice ulazilo nekoliko potkategorija granica. Fizičke granice odnose se na osobni prostor i fizički dodir te svjesnost o tome koje je ponašanje prikladno s obzirom na vrstu odnosa, dok se one krše kada nas netko dodiruje a da to ne želimo ili upada $\mathrm{u}$ naš intimni prostor a da mu za to nismo dali dozvolu. Intelektualne se granice odnose na misli i ideje te uključuju poštivanje tuđeg mišljenja, a krše se kada se nečije ideje i stavovi omalovažavaju. Emocionalne granice su one koje se odnose na ljudske osjećaje te uključuju ograničenja o tome kada dijeliti, a kada ne dijeliti osobne informacije s nekim, dok se one narušavaju kada netko omalovažava, negira ili kritizira tuđe osjećaje. Materijalne granice uključuju novac i druga materijalna dobra te se odnose na osobne odluke kako ćemo raspolagati svojim materijalnim resursima i s kime cemo ih dijeliti, dok se one krše kada se namjerno otuđe ili uništavaju tuđe stvari ili se nekog prisiljava da mu se daju ili posude tuđe stvari. Konačno, vremenske granice podrazumijevaju način na koji osoba raspolaže svojim vremenom i koliko vremena posvećuje određenom segmentu vlastitog života (npr. zdrave granice nalažu da se ostavi vremena za razne sfere života - posao, romantičnu vezu, prijatelje, hobi itd.), a one se krše kada od druge osobe zahtijevamo previše njenog vremena. ${ }^{10}$

Osobne se granice kreću zajedno s nama, tj. nosimo ih konstantno sa sobom poput karakterne crte gdje god idemo, te nas štite i u isto vrijeme utječu na sve vrste interakcija sa svijetom oko nas: drugim ljudima, ali i predmetima, idejama i iskustvima (na primjer, stvar je osobnih granica moj stav prema imanju kućnih ljubimaca, korištenju novih tehnologija ili podvrgavanju alternativnim oblicima liječenja). ${ }^{11}$

\subsection{Relacijske granice}

Za razliku od osobnih granica koje sežu i izvan okvira odnosa s ljudima, relacijske granice opisuju isključivo odnos između dvoje ili više ljudi (npr. majka-dijete, muž-žena, mladić-djevojka, prijateljica-prijateljica, učenica-učiteljica itd.) te utječu samo na ljude u konkretnom odnosu/interakciji. Relacijske su granice „implicitne emocionalne i psihološke granice koje pomažu komunicirati

10 Usp. https://www.therapistaid.com/worksheets/boundaries-psychoeducationprintout.pdf (17.4.2021.)

11 Usp. Thomas Horner, On the formation of personal space and self-boundary structures in early human development: The case of infant stranger reactivity, str. 148-177. 
pojedincima kako se funkcionira u odnosima“. ${ }^{12}$ One su uvijek pod utjecajem osobnih granica onih koji sudjeluju u komunikacijskom i interpersonalnom odnosu. I dok bi se osoba koja ima problem $\mathrm{s}$ definiranjem osobnih granica te zbog toga trpi, trebala podvrći individualnoj terapiji, kada je riječ o psihološkom interventu kod osoba koje imaju problema u relacijskim granicama (npr. romantični partneri ili roditelji-djeca) preporučljivo je uključiti se u partnersku/ obiteljsku terapiju. ${ }^{13}$

Jedno od najranijih psiholoških korištenja termina granica $u$ sedamdesetim godinama prošloga stoljeća bio je u teoriji obiteljskih sustava, i to u smislu relacijskih granica. Minuchin je u tom kontekstu definirao granice kao nevidljivu crtu razgraničenja između pojedinca, obiteljskog podsustava, te obitelji i nadsustava, a zadaća im je da predstavljaju pravila tko i koliko sudjeluje, a što je neophodno za zdravu obiteljsku strukturu. ${ }^{14}$ Granice su u tom smislu bile viđene kao skup pravila koja određuju dinamiku sudjelovanja u obiteljskim procesima u svrhu zaštite obiteljskog podsustava, poput na primjer nepisanog pravila prema kojemu djeci nije dopušteno sudjelovati u raspravi između supružnika. ${ }^{15}$ Kretchmar i Jacobvitz koriste termin „obrasci relacijskih granica“ kako bi opisali obiteljsku dinamiku kada je riječ o kršenju granica roditelja prema djeci, psihičko i fizičko/seksualno zlostavljanje djece te triangulaciju u kojoj se dijete ubacuje u bračni sukob. Svi ti primjeri ukazuju na granice koje se oblikuju i krše u relaciji između roditelja i djece pa ih se može klasificirati i kao generacijske granice. ${ }^{16}$ Napomenimo da je pitanje granica unutar obitelji, posebno u relaciji dijete-roditelj u postmoderni doživio značajne promjene $\mathrm{s}$ obzirom na prijašnja razdoblja u kojima se odgoj temeljio na autoritarnoj moći ne uzimajući puno u obzir djetetov integritet i djetetove granice. Suvremena razvojna psihologija naglašava važnost preispitivanja teme granica

12 Molly Kretchmar, Deborah Jacobvitz, Observing mother-child relationships across generations: Boundary patterns, attachment, and the transmission of caregiving, Family Process, 41 (2003.), 3, str. 354.

13 Usp. Anne Scott Stiles, Personal versus relational boundaries: concept clarification and therapeutic interventions, The Journal of Theory Construction \& Testing, 8 (2004.), 2., str. 75.

14 Usp. Salvador Minuchin, Families and family therapy, Harvard University Press, Cambridge, 1974., str. 53.

15 Usp. Arlene Vetere, Structural family therapy, Child Psychology \& Psychiatry Review, 6 (2001.), 3, str. 133-139.

16 Usp. Molly Kretchmar, Deborah Jacobvitz, Observing mother-child relationships across generations: Boundary patterns, attachment, and the transmission of caregiving, str. 351-374. 
$\mathrm{u}$ odnosu roditelji-djeca, ističući da granice nisu skup univerzalno primjenjivih pravila koja bi vrijedila za sve, tj. „univerzalna veličina za sve brojeve“, ${ }^{17}$ po kojoj su roditelji ti koji određuju granice djeci, već se predlaže da odrasli odrede svoje osobne granice te ih onda komuniciraju djeci i traže od djece da poštuju njihove granice. To se međutim više ne čini kroz autoritarnu moć, već osobni autoritet. $\mathrm{Na}$ taj način roditelj poštuje svoje granice, ali i integritet djeteta, te granice komunicira osobnim jezikom („JA porukama“ koje započinju sa „Želim...“, umjesto pribjegavanja „TI porukama“, i naredbama „Moraš...“ ili „Ne smiješ...“), preuzimajući odgovornost za vlastite osjećaje i raspoloženja. ${ }^{18}$

Osim obiteljskih i generacijskih, u relacijske granice spadaju još i rodne granice (granice između žena i muškaraca), društvene granice, granice uloga, profesionalne granice te kulturalne granice. ${ }^{19}$ Kada je o ovim posljednjima riječ, Kwon je uspoređivao pogled na granice između zapadnjaka i istočnjaka te je pokazao kako kulturološki kontekst iz kojeg dolazimo snažno utječe na osobne i relacijske granice pojedinca. Činjenica da su istočnjaci okrenuti ka kolektivizmu, a zapadnjaci individualizmu, uvelike utječe na definiranje vlastitih granica i veću ili manju mogućnost zalaganja za osobnu stvar i dobrobit u odnosu na zajednicu, sa svojim pozitivnim i negativnim posljedicama. Autor za primjer navodi vlastito iskustvo odrastanja u Koreji, gdje je sasvim normalno da djeca spavaju s roditeljima ili bakama i djedovima, dok će mnoga djeca u zapadnim zemljama već od samog rođenja imati svoju sobu i svoj krevet. ${ }^{20}$ Također, o kulturi će ovisiti i način na koji će se doživljavati i izražavati emocije: dok se $u$ azijskim istočnim kulturama smatra neadekvatnim pokazivati osjećaje $u$ javnosti te se preferiraju emocije niskog intenziteta, u zapadnim će se kulturama (posebno u npr. južnim kulturama, poput Italije, Španjolske, Latinske Amerike) poticati visoka razina emocija i ekspresivnost u njihovu javnom pokazivanju. ${ }^{21}$

17 Jesper Juul, Vaše kompetentno dijete, Oceanmore, Zagreb, 2017., str. 210.

18 Usp. Jesper Juul, Vaše kompetentno dijete, str. 219-217.

19 O relacijskim granicama vidi i Steve Duck, Odnosi među ljudima, Naklada Slap, Jastrebarsko, 2007., str. 214-218.

20 Usp. Soo-Young Kwon, Codependence and interdependence: Cross-cultural reappraisal of boundaries and relationality, Pastoral Psychology, 50 (2001.), 1, str. 39-52.

21 Usp. Nangyeon Lim, Cultural differences in emotion: differences in emotional arousal level between the East and the West, Integrative Medicine Research, 5 (2016.), 2, str. 105-109. 


\section{VRSTE GRANICA: NARUŠENE I ZDRAVE GRANICE}

I osobne i relacijske granice razlikuju se po svojoj „propustljivosti“. Način na koji se ljudi odnose prema drugima ovisi upravo o propusnosti i fleksibilnosti njihovih osobnih prostornih granica. ${ }^{22}$ $\mathrm{S}$ obzirom na relacijske granice, terminologija koja se koristi kako bi se objasnile narušene i zdrave granice jest sljedeća: razdvojene, pomiješane i uravnotežene granice. Kod razdvojenih granica riječ je o odnosu u kojem se nalaze dvije osobe koje su ekstremno različite, psihički i duhovno udaljene, identiteti su im toliko odvojeni da veoma teško mogu sagledati tuđe mišljenje i stvoriti zdravu interakciju dvosmjerne i kvalitetne komunikacije. Drugu krajnost predstavljaju pomiješane granice, a one se javljaju kod osoba kod kojih se fizički i psihički prostor preklapa u tolikoj mjeri da ne znaju gdje počinje jedan, a gdje drugi; oni žive u simbiozi, nisu u stanju prepoznati svoju jedinstvenost te gube autonomiju. Klasični primjer pomiješanih granica jest zaljubljeni par u početnoj fazi svoje veze, ili pak odnos roditelja i djeteta gdje postoji prevelika navezanost jednih na druge. Uravnotežene granice opisuju zdrav odnos između dvije osobe ili više njih koje imaju jedinstveni i dobro definiran psihički prostor, tj. identitet, znaju tko su i što im je važno, prepoznaju da je druga osoba također jedinstvena i vrijedna iako različita te se međusobno poštuju zbog onoga što jesu. ${ }^{23}$

Terminologija koja se koristi kada je riječ o oblicima „propusnosti“ osobnih granica jesu rigidne, porozne (otvorene) i fleksibilne granice. ${ }^{24}$ Rigidne granice imaju osobe koje su podigle visoke zidane ograde oko sebe te se fizički i psihički izoliraju od drugih, tj. druge ljude drže na distanci, nitko ih ne može dodirnuti, ne prihvaćaju vlastitu i tuđu ranjivost, nemaju povjerenja u ljude, teško ili nikako ostvaruju bliske odnose i intimnost te u konačnici ostaju izolirani od ljudi i uskraćeni davanja/primanja ljubavi. Oni imaju skup unutar-

22 Usp. Anne Scott Stiles, Diane Wilson, Kenneth Thompson, Description and application of personal boundary theory in traumatized adults through the use of Russian stacking dolls, Traumatology, 15 (2009.), 2, str. 60.

23 Usp. Anne Scott Stiles, Personal versus relational boundaries: concept clarification and therapeutic interventions, str. 73. Lisa Diamond ističe kako je sasvim normalno da su granice među osobama koje žive zajedno, poput romantičnih parova ili supružnika, daleko češće zamućene, tj. nejasne u odnosu na partnere koji žive odvojeno, a čije je granice lakše razgraničiti. Usp. Lisa Diamond, Sexuality in relationship, u: Jeffrey Simpson, Lorne Campbell (ur.), The Oxford handbook of close relationships, Oxford University Press, Oxford, 2013., str. 595.

24 Usp. Anne Scott Stiles, Personal versus relational boundaries: concept clarification and therapeutic interventions, str. 75. 
njih i vanjskih pravila ponašanja kojih se rigidno drže u odnosima prema drugima na način da sva pravila vrijede za sve i u svim situacijama. Na taj način nisu u stanju prilagoditi se specifičnoj situaciji te prilagoditi svoja pravila određenom kontekstu, umanjujući stupanj svojih komunikacijskih kompetencija te stvaranju ravnoteže između osobnih i relacijskih granica unutar interpersonalnog odnosa. ${ }^{25}$ Osobe s rigidnim granicama ili, kako ih Cloud i Townsend tipološki nazivaju, izbjegavači, teško traže pomoć i podršku za sebe, ne prepoznaju vlastite potrebe, u svoje „dvorište“ ne puštaju ni loše, ali ni dobro. ${ }^{26}$ „U srcu te borbe je konfuzija (...) Granice bi trebale biti u stanju 'disati', poput ograda s vratima koja dobro puštaju unutra, a zlo propuštaju van. (...) Bog je naše osobne granice osmislio tako da imaju vrata. On nam čak daje slobodu da njega, Boga, pustimo k sebi ili da ga odbacimo." 27

Ipak, čini se da osobe koje ćemo u svakodnevnom životu susresti mnogo češće jesu one koje imaju otvorene ili porozne granice tzv. popustljivci - a to znači da ne znaju odbiti zahtjeve i reći „ne“ kada bi to u svojoj suštini htjele (dakle, koriste pasivnu komunikaciju), olako ulaze $u$ interpersonalne odnose i prebrzo drugima iznose svoju intimu te generalno previše ugađaju drugima. Osobe koje imaju ovu vrstu konflikta s osobnim granicama, a ta je da su one nejasne i nedefinirane, „nemaju sposobnost da zaštite svoje srce“. ${ }^{28}$ Razlog tomu ponajčešće jest strah: da će povrijediti tuđe osjećaje, da će ostati sami i odbačeni, da će ih drugi doživjeti kao sebične, neduhovne i loše osobe/vjernike, da će osjećati grizodušje, da će u drugima izazvati bijes s kojim se neće znati nositi, i sl. ${ }^{29}$ U temelju ovih popustljivih, tj. otvorenih granica leži manjak samopouzdanja te pretjerani osjećaj odgovornosti za tuđe osjećaje: „Mnogi ljudi ne mogu reći 'volim te i ne želim učiniti to' jer smatraju da voljeti znači uvijek govoriti 'da' “30 Razvojni psiholozi naglašavaju da se problemi $\mathrm{s}$ granicama počinju razvijati u djetinjstvu, a osobe koje kao odra-

25 Usp. Kathleen Reardon, Interpersonalna komunikacija. Gdje se misli susreću, Alinea, Zagreb, 1998., str. 73.

26 Usp. Henry Cloud, John Townsend, Granice. Kada reći “da”, kako reći "ne" i preuzeti nadzor nad svojim životom, str. 48-50.

27 Henry Cloud, John Townsend, Granice. Kada reći "da", kako reći "ne" i preuzeti nadzor nad svojim životom, str. 49.

28 Henry Cloud, John Townsend, Granice. Kada reći "da", kako reći "ne" i preuzeti nadzor nad svojim životom, str. 47.

29 Usp. Henry Cloud, John Townsend, Granice. Kada reći "da", kako reći "ne" i preuzeti nadzor nad svojim životom, str. 47.

30 Henry Cloud, John Townsend, Granice. Kada reći "da", kako reći "ne" i preuzeti nadzor nad svojim životom, str. 90. 
sli imaju problem s odbijanjem neprimjerenih ili neželjenih zahtjeva vrlo su vjerojatno takvo ponašanje naučili u roditeljskom domu. „Da bismo bili istinoljubivi, odgovorni, slobodni i plemeniti ljudi kakvima Bog želi da budemo, od djetinjstva se moramo učiti granicama. Razvoj granica proces je koji traje, no njegove ključne faze odvijaju se u vrlo ranim godinama, u razdoblju formacije karaktera."31 Kad roditelji ne poštuju djetetov „ne“ kao odgovor, kad dijete uče da je odbijanje tuđih zahtjeva i potreba nešto loše pa ih za to možda i kazne, djetetu poručuju da drugi s njima mogu činiti što ih je volja. To kreće već od, za nas odrasle bezazlenih nagovaranja bebe da pojede još samo jedan zalogaj dok dijete okreće glavu na stranu i neverbalno šalje signale da je sito ili da mu ponuđena hrana ne odgovara. Na kraju dijete može popustiti i početi kršiti vlastite granice jer uči da njegov „ne“ u roditeljima stvara negativne emocije. Stoga je neophodno da dijete može prvo unutar sigurnosti obiteljskog doma, a onda i izvan njega izreći rečenice poput „neću“, „ne slažem se“, „to mi se ne sviđa“ „to je pogrešno“, „ne želim“i sl., a da za takve odgovore ne bude ukoreno. ${ }^{32}$

Konflikte s granicama nemaju samo osobe koje imaju problem s definiranjem i postavljanjem vlastitih osobnih granica, već i osobe koje ne poštuju tuđe granice. Njih se najčešće naziva kontrolorima, a njihov je osnovni problem taj što nisu u stanju čuti i doživjeti tuđi „ne“. Cloud i Townsend razlikuju dvije vrste kontrolora: agresivni kontrolori iskazuju verbalno i fizičko nasilje pokušavajući oblikovati druge tako da im se prilagode, ne shvaćajući na svjesnoj razini da netko može razmišljati i osjećati drugačije od njih samih te za odgovor prihvaćaju samo „da“. Manipulativni kontrolori koriste sva sredstva kako bi druge nagovorili i uvjerili da im kažu „da“ ne bi li se sve odvijalo u skladu s njihovim željama i potrebama, pritom se koristeći nametanjem osjećaja krivnje, a ako je potrebno i lažima. Cloud i Townsend o njima će reći: „Kontrolori su nedisciplinirani ljudi. Imaju slabo razvijenu sposobnost upravljanja vlastitim porivima

31 Henry Cloud, John Townsend, Granice. Kada reći "da”, kako reći "ne" i preuzeti nadzor nad svojim životom, str. 60. Usp. Jesper Juul, Granice, blizina, poštovanje. Na putu prema kompetentnom odnosu roditelj - dijete, Harfa, Split, 2021.

32 Usp. Henry Cloud, John Townsend, Granice. Kada reći "da", kako reći "ne" $i$ preuzeti nadzor nad svojim životom, str. 46. Autorica članka primijetila je kao roditelj da djeca veoma rano - u dobi čak mlađoj od dvije godine - počinju shvaćati koncept postavljanja osobnih granica te ukoliko ih roditelji tome uče i na to potiču ona su u mogućnosti svoje granice komunicirati i verbalizirati (npr. to ne želim, to je moja granica), te isto tako prepoznati i poštivati tuđe (npr. trogodišnja djevojčica izjavljuje da se drugo dijete u vrtiću nije željelo igrati s njom i da je to njegova granica koju je ispoštovala). 
i željama. (...) Jedini lijek za to jest prepustiti kontroloru da iskusi posljedice svoje neodgovornosti. I na koncu, kontrolori su izolirani. Ljudi ostaju uz njih iz straha, grižnje savjesti ili ovisnosti. (...) Ne možemo terorizirati druge ili ih mučiti grižnjom savjesti, a istodobno od njih očekivati da nas vole."33 I u ovom slučaju razlozi kontrolorovog ponašanja mogu se tražiti u ranom djetinjstvu, a jedan od motiva mogao bi biti nepostavljanje granica $u$ odnosu na dijete od strane roditelja. Naime, „od najranije dobi djeca trebaju moći prihvatiti granice svojih roditelja, braće i sestara i prijatelja. (...) Suštinski, ideja poštivanja tuđih granica temelj je za empatiju, za to da volimo druge onako kako bismo htjeli da nas drugi vole. Djeci treba biti udijeljena milost poštivanja njihovih 'ne' i trebaju naučiti istu milost udijeliti drugima."34

Problem s granicama imaju i osobe koje odbijaju pokazati odgovornost vezane uz ljubav prema bližnjima u situacijama u kojima raspolažu potrebnim sredstvima, a njih se u literaturu naziva neosjetljivcima. Tu spadaju osobe koje ignoriraju potrebe drugih ili se prema tim potrebama odnose kritički, ali i osobe s narcisoidnim crtama ličnosti koje su toliko okupirane vlastitim potrebama da ne vide i ne čuju druge zaokupljeni sami sobom. ${ }^{35}$

Neki od simptoma koji se javljaju kao posljedica slomljenih ili nezdravih granica jesu sljedeći: pojava sindroma žrtve, strah od iznošenja vlastitog mišljenja i posljedično stalno slaganje s drugima, nemogućnost govorenja 'ne', žrtvovanje sebe na vlastitu štetu, potreba da se druge stalno spašava i preuzima na sebe tuđe odgovornosti, manjak povjerenja u ljude, ulaženje i upad u tuđi fizički i/ili psihički prostor, ponašanje koje je previše ovisno ili pak previše neovisno, sklonost iskorištavanja u vezama, kao i ponašanja koja su pretjerano uslužna ili s druge strane prkosna. ${ }^{36}$ Također,

33 Henry Cloud, John Townsend, Granice. Kada reći "da”, kako reći "ne" i preuzeti nadzor nad suojim životom, str. 53.

34 Henry Cloud, John Townsend, Granice. Kada reći "da", kako reći "ne" i preuzeti nadzor nad svojim životom, str. 185.

35 Usp. Henry Cloud, John Townsend, Granice. Kada reći "da", kako reći "ne" i preuzeti nadzor nad svojim životom, str. 54-55.

36 Usp. Sue Evans, Shame, boundaries and dissociation in chemically dependent, abusive and incestuous families, str. 157-179; Maureen McEvoy, Repairing personal boundaries: Group therapy with survivors of sexual abuse, str. 62-79.; Jaquelin Resnick, From hate to healing: Sexual assault recovery, Journal of College Student Psychotherapy, 16 (2001.), 112, str. 43-64; Rene Geanellos, Understanding the need for personal space boundary restoration in women-client survivors of intrafamilial childhood sexual abuse, International Journal of Mental Health Nursing, 12 (2003.), str. 186-193. 
postoje i brojne psihičke i/ili psihosomatske smetnje i bolesti koje se mogu razviti kao posljedica dugoročnog kršenja vlastitih granica, poput razvoja depresije, kompulzivnog poremećaja, impulzivnog ponašanja, kroničnog stida, osjećaja besmisla, napadaja panike, fobija, suicidalnih misli, bolesti krvožilnog sustava, kožnih bolesti i sl. ${ }^{37}$ Naglasimo da je najlakše prepoznati da se naše osobne i relacijske granice krše na temelju emocija koje osjećamo u određenim situacijama i odnosima, a riječ je o onim emocijama koje najčešće definiramo kao negativne: ljutnja, strah, sram, nelagoda.

Kao što je Marry Ann Donaldson ustvrdila, ljudi koji su visoko podigli betonske ograde ostaju izolirani, oni koji imaju niske ograde od lanaca nisu u stanju kontrolirati svoju intimu i privatnost previše vjerujući svima, a oni koji imaju srednje visoke ograde od drvenih stupića s vratima imaju zdrave, fleksibilne granice. ${ }^{38}$ Naglasimo odmah i to da većina ljudi koristi više vrsta granica u međuljudskim odnosima pa tako netko može imati rigidne granice $u$ poslovnom okruženju, u obiteljskom ambijentu porozne, dok su u društvu prijatelja one najfleksibilnije. Fleksibilne granice jesu najzreliji i najzdraviji oblik granica kada je riječ i o relacijskim i o osobnim granicama. Osoba sa zrelim, zdravim i fleksibilnim granicama ne kompromitira vlastite vrijednosti radi drugih, dijeli osobne informacije na prikladan način (niti premalo niti previše), poznaje osobne želje i potrebe te ih je u stanju komunicirati, zna reći „ne“ te prihvaća tuđi „ne“, u stanju je graditi bliske odnose. ${ }^{39}$ Zdrave granice nikoga ne kontroliraju, ne vrijeđaju niti ne uvjetuju. Dokaz zdravih granica uključuju asertivno ponašanje, ponos s obzirom na vlastiti izgled i uspjehe te poštivanje tuđih ideja, vrijednosti i privatnosti. ${ }^{40}$ Osoba koja ima fleksibilne granice zna napraviti ravnotežu između postizanja osobnih i relacijskih ciljeva, može reći „ne“ drugima bez osjećaja grizodušja, i to ne samo manipulativnim zahtjevima već i legitimnim potrebama bližnjih odluči li da se iz nekog razloga ne želi žrtvovati i

37 Usp. Henry Cloud, John Townsend, Granice. Kada reći "da", kako reći "ne" i preuzeti nadzor nad svojim životom, str. 20.

38 Prema Anne Scott Stiles, Personal versus relational boundaries: concept clarification and therapeutic interventions, str. 74 .

39 Usp. https://www.therapistaid.com/worksheets/boundaries-psychoeducationprintout.pdf (17. 4. 2021.).

40 Usp. Sue Evans, Shame, boundaries and dissociation in chemically dependent, abusive and incestuous families, str. 157-179.; Maureen McEvoy, Repairing personal boundaries: Group therapy with survivors of sexual abuse, str. 62-79; Jaquelin Resnick, From hate to healing: Sexual assault recovery, str. 43-64.; Rene Geanellos, Understanding the need for personal space boundary restoration in women-client survivors of intrafamilial childhood sexual abuse, str. 186-193. 
da osoba u potrebi može sama preuzeti odgovornost za svoje breme. Temelj za takvo ponašanje možemo pronaći i u Novom zavjetu, gdje Isus govori svojim učenicima da je i „ne“ legitiman odgovor: „Vaša riječ neka bude: 'Da, da, - ne, ne!'“ (Mt 5,33-37). Isus nas poučava da ljubimo svoje bližnje kao sebe same, on sam postavlja granice te ne komunicira sa svima na isti način: ne odgovara svima na pitanja, ne liječi sve ljude. Također, evanđelist Marko izvješćuje o tome kako je Isus uputio svoje učenike da nakratko napuste svoje poslanje kako bi odmorili: „Hajdete i vi u osamu na samotno mjesto, i otpočinite malo.' Jer mnogo je svijeta dolazilo i odlazilo pa nisu imali kada ni jesti. Otploviše, dakle, lađom na samotno mjesto, u osamu“ (Mk 6,30-34). Bog općenito kroz povijest spasenja ne govori svima i uvijek „da“, ne brinući se „da bi nas njegove granice mogle povrijediti. On zna da moramo preuzeti odgovornost za vlastite živote, a 'ne' nam pomaže da učinimo baš to“. ${ }^{41}$ Bog isto tako poštuje naše 'ne' kroz dar slobodne volje.

Fleksibilne granice u suštini znače da ih mi možemo iznova redefinirati, prilagođavati situaciji i osobama s kojima smo u interakciji. Na primjer, ako osoba na naše postavljene granice u nekom konkretnom slučaju reagira s ljubavlju i promijeni svoje ponašanje, granice možemo ponovno definirati u odnosu na tu osobu.

\section{KOMUNICIRANJE GRANICA KROZ ASERTIVNU KOMUNIKACIJU}

Prvi korak u komuniciranju osobnih i relacijskih granica jest komunikacija istih samima sebi, a to znači biti svjestan svojih granica, prihvatiti ih kao legitimne u skrbi o samima sebi. Sljedeći jednako važan korak je da se granice jasno komuniciraju unutar interpersonalnog odnosa. Zbog često nerealnih i krivih strahova od odbacivanja i gubitka ljubavi, a o čemu se govorilo u prijašnjem poglavlju, ljudi se pasivno povlače i stvaraju svoje tajne granice koje ne žele iskomunicirati, dok u sebi zamjeraju. Kao što naglašavaju Cloud i Townsend, kada granice ne komuniciramo direktno, one će tada biti obznanjene putem manipulacije, ogorčenosti, frustracije. ${ }^{42}$ To naravno dugoročno šteti međuljudskim odnosima, posebno bliskosti i intimnosti.

41 Henry Cloud, John Townsend, Granice. Kada reći “da”, kako reći "ne” i preuzeti nadzor nad svojim životom, str. 109.

42 Usp. Henry Cloud, John Townsend, Granice. Kada reći "da”, kako reći "ne” i preuzeti nadzor nad svojim životom, str. 99. 
Granice možemo komunicirate na više načina, i neverbalno i verbalno. Jedan od zasigurno najučinkovitijih načina jest komunicirati ih verbalno direktno i otvoreno: „Naše riječi ljudima daju do znanja naše stajalište, ali i daju osjećaj 'rubova' koji pomažu da nas identificiraju. " ${ }^{43}$ Temeljne riječi za komuniciranje naših granica jesu „želim“ i „ne želim“, „hoću“ i „neću“, „sviđa mi se“ i „ne sviđa mi se“, „Volim“ i „ne volim“, a za postavljanje granica koje bi mogle biti narušene osnovna je čestica „ne“. Sposobnost pravilnog odbijanja tuđih zahtjeva, tj. izgovaranje riječi „ne“, „ne želim“ ili „neću“ spada u jednu od temeljnih komunikacijskih vještina, a naziva se asertivnost. Najbolji način komuniciranja osobnih i relacijskih granica jest asertivni govor, a to znači da vlastite osjećaje, misli i uvjerenja komuniciramo na izravan, otvoren i iskren (neagresivan, neosuđujući i nereaktivan) način, poštujući u isto vrijeme tuđa prava, te odbijamo nerazumne ili nepoželjne zahtjeve bez osjećaja straha i krivnje. To je vještina koja pomaže adekvatnom postavljanju granica u očuvanju vlastitih prava, a da se pritom ne naruše tuđa prava. ${ }^{44}$ Drugim riječima, asertivnim ponašanjem potvrđujemo svoju vlastitu vrijednost i dostojanstvo uz istovremeno poštivanje vrijednosti i dostojanstva drugih. ${ }^{45}$ „U asertivnom ponašanju ljudi uvijek teže pronaći ravnotežu između potreba obje strane. Potrebno je razlikovati ponašanje i odluke za koje ste odgovorni i preuzeti tu odgovornost, ali također prepoznati ponašanje drugih odraslih osoba za koje niste odgovorni i za čije postupke ne biste trebali kriviti sebe ili trpjeti posljedice.“46

Osoba sa zdravim granicama i asertivnom komunikacijom imat će neke od sljedećih karakteristika: samopouzdana je, aktivno sluša sugovornika, pokazuje empatiju, poštuje druge te isto traži za sebe, ne okoliša, već jasno i direktno govori što misli, želi i osjeća, pozitivno izriče kritiku, zna pohvaliti druge, iskrena je i nije sarkastična, preuzima odgovornost za svoje riječi i djela, jasno i transparentno postavlja granice, spreman/na je ispričati se kad pogriješi, neverbalna komunikacija u skladu je s verbalnom itd. ${ }^{47}$ Asertivna se komunikacija smatra posebno važnom u situacijama kao što su traženje vlastitih prava, suprotstavljanje nepravdi, izražavanje inte-

43 Usp. Henry Cloud, John Townsend, Granice. Kada reći "da", kako reći "ne" i preuzeti nadzor nad svojim životom, str. 30.

44 Usp. Arthur Lange, David Rimm, Janet Loxley, Cognitive-bihevioral assertion training precedures, The Counseling Psychologists, 5 (1975.), 4, str. 37.

45 Draženka Skupnjak, Rješavanje konflikata i vještine asertivnosti, Varaždinski učitelj - digitalni stručni časopis za odgoj i obrazovanje, 3 (2020.), 3, str. 13.

46 Zoran Zlatković, Milislav Milinković, Jelena Vukičević, Sanja Batić, Priručnik za nenasilje, Organizacija kreativnog okupljanja OKO, Beograd, 2006., str. 36.

47 Usp. Draženka Skupnjak, Rješavanje konflikata i vještine asertivnosti, str. 13. 
resa i želja, odbijanje zahtjeva, davanje i primanje komplimenata, upućivanje konstruktivnih kritika. ${ }^{48}$

Asertivna komunikacija u svojoj je biti nenasilna i suosjećajna komunikacija koja izaziva u sugovornicima želju za suradnjom, dok je njezina temeljna tehnika korištenje tzv. „JA poruka“ - osobnog govora u kojem osoba izražava vlastite osjećaje, vrijednosti, stavove, želje i namjere u odnosu na drugoga, a da tog drugog ne napada, ne kritizira i ne vrijeđa ili u drugome traži krivca. ${ }^{49}$ Konstruktivna „JAporuka“ sastoji se od tri dijela: „opisa ponašanja koje nam smeta bez osuđivanja, izražavanja svojih osjećaja i pojašnjavanja konkretnih i stvarnih posljedica opisanog ponašanja s prijedlogom buduće akcije." ${ }^{50}$ Dok će tako osoba koja koristi neasertivne „TI poruke“ reći prijatelju koji kasni: „Uvijek kasniš i baš me živciraš, jako si neorganiziran. Moraš naučiti dolaziti na vrijeme“, osoba koja koristi „JA poruku“ reći će sljedeće: „Ne volim kada kasniš na naše sastanke, a da me o tome ne obavijestiš, to me čini nervoznom. Ako sljedeći put zakasniš na dogovor, neću te više čekati.“ Na taj način jasno dajemo drugima do znanja što hoćemo ili što nećemo tolerirati, tj. transparentno im pokazujemo tko smo uistinu mi kroz komuniciranje vlastitih granica.

Dakle, kroz asertivnu komunikaciju mi dajemo do znanja koje su naše granice, kako se osjećamo te koje su moguće posljedice koje ćemo poduzeti ako druga strana ne odluči uzeti u obzir naše granice, tj. naše legitimne potrebe. Kao što se uočava iz navedenog primjera, za određene oblike ponašanja koje narušavaju naše granice postoje konkretne posljedice: „Posljedice nam daju dobru bodljikavu žicu za našu ogradu. Daju ljudima do znanja da ne mogu olako doći na naš posjed te da mi ozbiljno poštujemo sami sebe. Daju im do znanja i koliko smo predani odluci da živimo sukladno vrijednostima koje su nam važne i za koje ćemo se boriti da ih zaštitimo i očuvamo."51 (...) „Odvajajući se od takvih ljudi, zapravo štitimo ljubav zato što zauzimamo stav i postavljamo se protiv onoga što uništava ljubav."52

48 Usp. Živko Stojčić, Lada Perković, Ina Stašević, Nevena Stojčić, Darko Ropac, Ispitivanje odnosa percepcije sukoba i asertivnosti kod medicinskih sestara, str. 260.

49 Usp. Mirsada Džaferović, Nonviolent communication, empathy and assertion as modern strategies in the study of overcoming conflicts, Metodički obzori, 7 (2012.), 1, str. 107.

50 Draženka Skupnjak, Rješavanje konflikata i vještine asertivnosti, str. 14.

51 Henry Cloud, John Townsend, Granice. Kada reći "da", kako reći "ne" i preuzeti nadzor nad svojim životom, str. 33-34.

52 Henry Cloud, John Townsend, Granice. Kada reći "da", kako reći "ne" i preuzeti nadzor nad svojim životom, str. 39. 


\section{ZAKLJUČAK}

Iako smo se u članku uglavnom bavili psihološkim pristupom fenomenu osobnih i relacijskih granica, u zaključku želimo naglasiti da se granice uklapaju i u kršćansku antropološku misao budući da nam kršćanska Objava kako je zapisana u Svetome pismu prikazuje Boga koji, bivajući osoba, posjeduje osobne granice te ih jasno i asertivno komunicira. I u Starom i u Novom zavjetu susrećemo Boga koji jasno definira „pravila igre“ te komunicira posljedice nepoštivanja njegovih granica (Post 2,17), poštuje tuđu slobodu (Mk 6,5), govori „da“ i „ne“ bez osjećaja grizodušja (2 Kor 12,9), uzima vrijeme za sebe (Mk 6,30-34), ne odgovara na sva postavljena mu pitanja (Iv 18,21 ), uči nas zdravoj ljubavi prema sebi i posljedično ljubavi prema bližnjima (Mt 22,34-40), dopušta da mu kažemo „ne“ i zbog toga se ne ljuti (Iv 18,17), podučava nas da se ne možemo svima svidjeti i svima udovoljiti te da nije dobro ako nas svi samo hvale $($ Lk 6,26). Tako nas Bog uči da je dobro, dapače, neophodno imati i njegovati osobne granice koje nas vode $\mathrm{k}$ istinskoj autentičnosti.

Osobne granice pomažu nam da definiramo naš osobni identitet i integritet. Posjedovanje i vrednovanje osobnih granica znak su zdrave ljubavi prema sebi kao i zdravog samopoštovanja. Prepoznavanje i prihvaćanje vlastitih granica odraz su ljudske zrelosti, omogućuju bivanje u miru sa samim sobom te stvaraju osjećaj sigurnosti, temelj su duhovnog i psihičkog rasta te bliskih interpersonalnih odnosa. U bilo kojoj situaciji, granice se uvijek odnose na osobnu slobodu, odgovornost i samokontrolu. „Baš kao što vlasnik postavlja ogradu oko svojeg posjeda, očekuje se i da svaki čovjek postavi mentalne, fizičke, emocionalne i duhovne ograde vlastitom životu kako bi znao što to sve ulazi u njegov 'posjed' te posljedično znao za što jest, a za što nije odgovoran." 53 Upravo je pitanje odgovornosti ključni element fleksibilnih granica, koje smo u članku definirali kao najzdraviji oblik osobnih i relacijskih granica, iz razloga da brinući i skrbeći o samima sebi ne bismo odlutali u pretjerano sebeljublje ili narcizam. Stoga je na kraju važno istaknuti razliku između odgovornosti za i odgovornosti prema. Naime, svatko od nas odgovoran je za sebe, no ne i za druge. Međutim, imamo odgovornost prema drugima. Tu se možemo pozvati na apostola Pavla, koji u poslanici Galaćanima piše: „Svatko će nositi svoj teret“ (Gal 6,5), a to znači da svatko od nas pojedinačno ima svoju životnu misiju koju može nositi samo ona/on i za koju je odgovorna samo ona/on. U isto

53 Henry Cloud, John Townsend, Granice. Kada reći "da", kako reći "ne" i preuzeti nadzor nad svojim životom, str. 20. 
vrijeme Pavao piše i sljedeće: „Nosite jedni bremena drugih i tako cete ispuniti zakon Kristov!“ (Gal 6,2), a to znači da imamo odgovornost prema drugima, prema onima koji nemaju dovoljno vlastitih snaga i znanja da nose svoje životne terete te im je potrebna tuđa pomoć. Iz tog je razloga važno spoznati gdje je granica moje odgovornosti i gdje započinje tuđa odgovornost. ${ }^{54}$ Žrtvovati se za drugoga, odreći se samog sebe kako bismo nekome pomogli u onome što on sam nije u stanju, znači biti velikodušan i altruističan, znači slijediti Kristov primjer sebedarja. No želimo li pomicati i mijenjati svoje osobne granice poradi kršćanskog sebedarja i poziva na ljubav prema bližnjem, to je potrebno činiti u potpunoj slobodi i iz ljubavi, a ne iz grizodušja i osjećaja krivnje. To također ne znači da moramo dati sve što bilo tko od nas traži i u svakom trenutku. Svaka osoba u skrbi za sebe svjesno kontrolira vlastito davanje, a da bi došla do tog izbora, potrebne su joj jasne granice te zdrava i uravnotežena ljubav prema sebi i bližnjemu.

\section{PERSONAL BOUNDARIES AS THE FOUNDATION OF INTERPERSONAL RELATIONSHIPS AND SELF-CARE}

\section{Summary}

The article deals with the topic of defining and reflecting on personal boundaries in the context of caring for one's own psychophysical and spiritual health. Personal boundaries help us define our personal identity, integrity, close relationships and contribute to creating a sense of security. They are learned from the earliest childhood and what the boundaries will be largely depends on how the parents / guardians communicated their own boundaries and whether they respected the child's personal integrity and possible disagreements. Recognizing, setting and communicating personal boundaries also have their biblical inspirations since God in the Holy Scripture is able to say "no" and gives man free will by allowing him freedom of choice. This article therefore seeks to define what personal boundaries are, how they develop, difference between "healthy" and "sick" boundaries, how setting personal boundaries can help us build better interpersonal relationships and how the idea of boundaries fits into Christian anthropology. In this con-

54 Usp. Henry Cloud, John Townsend, Granice. Kada reći "da", kako reći "ne" i preuzeti nadzor nad svojim životom, str. 25-26. 
text, we will also talk about assertiveness as a communication skill with which we communicate personal boundaries in a correct and healthy - non-aggressive, non-judgmental and non-reactive - way.

Keywords: personal boundaries, assertiveness, interpersonal relationship, integrity, responsibility, Christianity and boundaries 